!!!STRANG-291-ChallengesofandChallengestoOriginAlisM.doc (Do Not Delete)8/9/2013 3:37 PM

\title{
THE CHALLENGE OF, AND CHALLENGES TO, ORIGINALISM
}

\section{THE CHALLENGE OF ORIGINALISM: THEORIES OF CONSTITUTIONAL INTERPRETATION. Grant} Huscroft $^{1} \&$ Bradley W. Miller ${ }^{2}$ eds. Cambridge, Cambridge University Press. 2011. Pp. ix +305 . $\$ 99.00$ (cloth).

\section{Lee J. Strang}

\section{INTRODUCTION}

The Challenge of Originalism does many things well: it showcases the sophistication of current originalist scholarship; it displays the resonance that originalist arguments have with diverse and international audiences; and it reminds us that originalists are far from having won the debate. The Challenge of Originalism brings together some of the leading lights of originalist scholarship, and puts them in conversation with each other and with prominent critics.

The Challenge of Originalism also, as all collections must, leaves out some important topics. Most prominent is originalism's relationship to nonoriginalist precedent, a subject of significant scholarly interest over the past ten years. Also, The Challenge of Originalism introduces some of the key recent originalist moves, such as incorporating the concept of constitutional construction, without fully elucidating them.

The essays in The Challenge of Originalism are consistently nuanced and thought-provoking. The Challenge of Originalism includes introductory material to originalism and the debates surrounding it, and its consistently high level of sophistication

1. Professor of Law, University of Western Ontario.

2. Associate Professor of Law, University of Western Ontario.

3. Professor of Law, University of Toledo College of Law. 
!!!StRANG-291-ChALLENGESOFANDCHALLENGESTOORIGINALISM.DOC (Do Not Delete)8/9/2013 3:37 PM

also makes it valuable to scholars already engaged in these debates.

In Part II, I first describe the important contributions made by and in The Challenge of Originalism. In particular, The Challenge of Originalism showcases originalism's sophistication and broad appeal. Then, in Part III, I suggest two important and unresolved challenges to originalism: (1) fully explaining the nature and scope of constitutional construction; and (2) describing what role, if any, nonoriginalist precedent retains in originalism. I end, in Part IV, by suggesting that the essays exemplify the chief reason for originalism's continuing and broad-based allure-the reason it presents a challenge-the Constitution's writtenness.

\section{THE CHALLENGE OF ORIGINALISM}

\section{A. ORIGINALISM'S SOPHISTICATION}

The Challenge of Originalism is primarily composed of essays that-among other things they do well-exhibit originalism's increasing sophistication. The first three chapters present a description of originalism, its origin and current state (pp. 12-41, 70-86), along with a defense of originalism (pp. 4269). Chapters four and five provide a window into the newlyreinvigorated original intent originalism position (pp. 87-119), and chapter six displays the potential impact of the adoption of original meaning originalism in the context of Canadian constitutional law (pp. 120-46). Chapters seven through nine exemplify the role that constitutional settlement plays and can play in justifications of originalism (pp. 147-222). Lastly, chapters ten through twelve contain critiques - some sympathetic and some not - of originalism, especially its original meaning version (pp. 223-99).

Both the originalists and their critics in The Challenge of Originalism powerfully deploy a wide variety of concepts, distinctions, and arguments. For this reason, The Challenge of Originalism is not solely for the newly initiated. ${ }^{4}$ Lawrence Solum's essay, "What is Originalism? The Evolution of Contemporary Originalist Theory," is appropriately first in the collection because it provides a clear introduction to

4. The essays are well written and describe originalism's complexity in an accessible manner. 
!!!StrANG-291-ChALLENGESOFANDCHALLENGESTOORIGINALISM.DOC (Do Not Delete)8/9/2013 3:37 PM

originalism's theoretical evolution over the past forty years (pp. 12-41). He first introduces readers to originalism's various incarnations: original intent, original understanding, original meaning, and original methods (pp. 16-26). Then, Solum describes the major intellectual moves made by (many) originalists to advance originalism: the distinction between original applications and original meaning; the distinction between constitutional interpretation and construction; and the fixation and contribution theses (pp. 23-26, 33-36). Solum's own most important additions are the fixation and contribution theses (pp. 33-36).

The best example of originalism's increased intricacy, on display in The Challenge of Originalism, is the concept of constitutional construction. As described by Solum, construction "determin[es] the legal effect of the constitutional text" (p. 23). This concept is one of the key moves made by those originalists who advocate original meaning originalism, ${ }^{5}$ and it is tied to a host of other concepts, such as legal underdeterminacy ${ }^{6}$ (p. 23). For instance, Jeffrey Goldsworthy states that "interpretation is frequently unable to resolve interpretative problems raised by constitutions that ... are often ambiguous, vague, contradictory, insufficiently explicit, or even silent" (p. 60).

Many of the "new originalists" place a lot of weightperhaps too much ${ }^{7}-$ on construction. For example, Keith Whittington argues that originalism can accommodate much of the "pluralism" in constitutional argumentation within the concept of construction (pp. 79, 82). When the Constitution's original meaning is underdetermined, according to Whittington, originalists may resort to the various "modalities" of constitutional argumentation, but in a manner "carefully disciplined by the overarching interpretative enterprise" (p. 79).

5. Though, there is no necessary reason why originalists of other stripes, such as advocates of original intent originalism, could not make the same move. See, e.g., Richard S. Kay, Original Intention and Public Meaning in Constitutional Interpretation, 103 Nw. U. L. REV. 703, 719-25 (2009) (arguing that original meaning originalism is relatively more open to underdeterminacy than original intent originalism). Original methods originalists have suggested that their conception of originalism "resolve[s]" constitutional ambiguity and vagueness, and would therefore eliminate the necessary precondition for employing construction. John O. McGinnis \& Michael B. Rappaport, Original Methods Originalism: A New Theory of Interpretation and the Case Against Construction, 103 Nw. U. L. REV. 751, 752-53 (2009).

6. See Lawrence B. Solum, On the Indeterminacy Crisis: Critiquing Critical Dogma, 54 U. CHI. L. REV. 462, 473 (1987) (providing the seminal definition of underdeterminacy).

7. I suggest below, in Part III, how this may be the case. 
!!!StrANG-291-ChALLENGESOFANDCHALLENGESTOORIGINALISM.DOC (Do Not Delete)8/9/2013 3:37 PM

Similarly, Goldsworthy claims that, within constitutional construction, "judges may be forced to act creatively and... consider[] matters such as consistency with general legal doctrines and principles, public policy, and justice" (p. 61). Indeed, Lawrence Solum labels original meaning originalists' embrace of construction "perhaps their most important move" (p. 23), and for two reasons: (1) originalism is more descriptively plausible when it "acknowledges ... the fact of constitutional underdeterminacy"; and (2) constitutional construction "open[s] the door for reconciliation between originalism and living constitutionalism" (pp. 23-24).

The Challenge of Originalism also provides a helpful introduction to the intricate intra-originalism debate over original intent and original meaning. Lawrence Solum, Jeffrey Goldsworthy, and Keith Whittington represent the original meaning camp. Goldsworthy directly argues in favor of original meaning originalism (pp. 46-51), and Solum and Whittington describe the benefits originalists reap from its adoption (pp. 1241, 70-86). For example, as noted, Solum suggests that original meaning originalism "opened the door for reconciliation between originalism and living constitutionalism" (p. 24).

Original intent originalists, represented in The Challenge of Originalism by Larry Alexander and Stanley Fish, are direct in their support for original intent originalism and criticism of original meaning originalism (pp. 87-119). Although originalism is currently most prominently associated with original meaning, ${ }^{9}$ advocates of original intent have continued to proffer strong cases for original intent and criticisms of original meaning. Alexander's and Fish's contributions are no exception. Alexander, for instance, offers a host of arguments: original intent better fits how humans interpret other texts (pp. 87-89); the common reasons for adopting original meaning are unpersuasive (pp. 90-91); and original intent best fits

8. For Professor Solum's more recent published thoughts on such a reconciliation see Lawrence B. Solum, Faith and Fidelity: Originalism and the Possibility of Constitutional Redemption, 91 TEX. L. REV. 147 (2012) (reviewing JACK M. BALKIN, CONSTITUTIONAL REDEMPTION: POLITICAL FAITH IN AN UNJUST WORLD (2011), and JACK M. BALKIN, LiVING ORIGINALISM (2011)).

9. See Keith E. Whittington, The New Originalism, 2 GeO. J.L. \& PuB. PoL'Y 599 (2004) (providing a thorough summary of the widespread move to original meaning).

10. Other prominent original intent originalists include: Richard S. Kay, Adherence to the Original Intentions in Constitutional Adjudication: Three Objections and Responses, 82 Nw. U. L. REV. 226 (1988), and Saikrishna Prakash. Larry Alexander \& Saikrishna Prakash, "Is that English You're Speaking?" Why Intention Free Interpretation is an Impossibility, 41 SAN DIEGO L. REV. 967 (2004). 
!!!Strang-291-ChallengesofandChallengestoOriginalisM.DOC (Do Not Delete)8/9/2013 3:37 PM

interpretation of the actual document in the National Archives instead of another-possibly hypothetical-document (pp. 9395). ${ }^{11}$

Originalism's sophistication is also displayed in the complex exchanges between the originalists and their critics. Jeffrey Goldsworthy's contribution, "The Case for Originalism," is a clearly presented articulation of "[t]he best argument for originalism" (p. 42). Goldsworthy lists and then defends eight propositions, each of which builds on earlier ones (pp. 42-67). For example, Proposition 1 is: "A Constitution, like any other law, necessarily has a meaning that pre-exists judicial interpretation of it" (p. 44) (emphasis omitted). Goldsworthy responds to criticisms of this proposition from a number of sources, including prominent critic of originalism, Mitchell Berman (pp. 44-46).

The Challenge of Originalism contains three critical essays, by Steven D. Smith, Mitchell N. Berman, and Brian H. Bix. Berman's essay is the most directly confrontational and, in Berman's exchanges with his interlocutors, the reader witnesses an impressive display of erudition (by both parties). For example, Berman and Solum both describe what Solum calls the "contribution thesis" of originalism - that the Constitution's original meaning contributes to constitutional law-and the nuanced distinction between the Constitution's semantic content and its legal content (pp. 32-38, 257 n.17).

Another example occurs later in Berman's essay, where he offers a coherentist criticism of originalism. Rooted in the method of a reflective equilibrium, Berman argues that originalism cannot account for Americans' case-specific constitutional judgments, such as the wide-spread intuition that John McCain was eligible to be president despite the Natural Born Citizenship Clause's contrary original meaning (pp. 258-73). To this line of argument, Alexander "den[ies] ... that one does or can have constitutional or legal intuitions that pre-exist" (p. 97). In turn, Berman attempts to rebut Alexander's point (pp. 268 n.49).

11. Many of Alexander's claims resonate with those of Richard Kay. Kay, supra note 5, at 714-19; see also Richard S. Kay, American Constitutionalism, in CONSTITUTIONALISM: PHILOSOPHICAL FOUNDATIONS 29-33 (Larry Alexander ed., 1998) (arguing that original intent originalism is required because it best facilitates "implementation of a regime of constitutional restraints ... created by the constitutionmakers"). 
!!!StrANG-291-ChALLENGESOFANDCHALLENGESTOORIGINALISM.DOC (Do Not Delete)8/9/2013 3:37 PM

Bix's essay, "Constitutions, Originalism, and Meaning," sounds in the vein of constructive criticism. Bix, for instance, suggests that one of the key original meaning originalist movesto distinguish constitutional meaning from expected applications of that meaning-may fail to take into account the normative context of law (pp. 286-91). Bix argues that, instead, meaning and application are often related in complicated ways and, if that is the case, then originalists' clean distinction between interpretation and construction may be vulnerable.

Smith's essay, "That Old-Time Originalism" (pp. 223-45), is perhaps the most intriguing of all, from an originalist's perspective. Smith characterizes himself as "an originalist sympathizer" who counsels that originalism's increased sophistication-so prominently displayed throughout The Challenge of Originalism-is, or is partly, a negative development. After detailing some of the ways originalist theory has become more elaborate, Smith argues that originalism's increased"scholasticized," Smith says-sophistication has its costs. In particular, Smith identifies "exclusion and dissolution": exclusion of everyone but the most determined and intelligent from the debate, and dissolution of originalism as a coherent position on constitutional interpretation (pp. 227-33). Below, and in Part IV, I expand on Smith's suggestion that originalism's sophistication is harming originalism.

Given Smith's reliance on and analogy to the Christian tradition, I wonder if that same tradition suggests a possible distinction between Smith's two identified costs of originalism's increasing sophistication. First, one could argue that, as Christian theologians developed and adopted more sophisticated tools, the gap between theologians and average Christians widened, with the likely exclusion of average Christians from high-end theological discussions. This is a cost, but one that nearly all Christian denominations have thought worth bearing, ${ }^{12}$ and for good reason. Theological erudition is not a prerequisite to being a good Christian, ${ }^{13}$ and Christian churches have found that theological sophistication provides a host of benefits, such as greater insight into Divine Truth. ${ }^{14}$

12. Some descendants of the Radical Reformation constitute rare exceptions. KENNETH SCOTT LATOURETTE, A HISTORY OF CHRISTIANITY 788-90 (1953).

13. John Henry Cardinal Newman articulated this claim in JOHN HENRY NEWMAN, AN ESSAY IN AID OF A GRAMMAR OF ASSENT 123-31 (Univ. of Notre Dame Press, 1979) (1870).

14. See, e.g., John Henry Cardinal newman, An Essay on the 
Similarly, sophistication in constitutional interpretation is not necessary to being a good citizen, lawyer, or judge (or even a good legal scholar!). ${ }^{15}$ And originalism's increased sophistication has yielded significant benefits. For example, originalist arguments are taken seriously by the Supreme Court, ${ }^{16}$ in the legal academy, ${ }^{17}$ and have exerted gravitation force even when not successful. ${ }^{18}$

Second, dissolution has clearly occurred to and harmed Christianity. Christianity's fragmentation has taken many forms, and took place over an extended period of time, but it is unlikely that theological sophistication was a major cause, at least of Western Christianity's dissolution in the sixteenth century. ${ }^{19}$ Instead, standard accounts of the Reformation cite to a host of other factors, such as the personal corruption of many of the Church's leaders and clerics, that contributed to its occurrence. ${ }^{20}$

There are deep divisions among originalists over construction, ${ }^{21}$ nonoriginalist precedent, ${ }^{22}$ the appropriate form of

DeVelopment of Christian Doctrine 29-30 (Univ. of Notre Dame Press 6th ed. 1989) (1878) (summarizing his "Theory of the Development of Doctrine"). Of course, increased theological sophistication is also a result of the Divine mandate to "be[] ready always to satisfy every one that asketh you a reason of that hope which is in you." 1 Peter $3: 15$.

15. Smith makes something like this distinction at the end of his essay (p. 244).

16. E.g., Dist. of Columbia v. Heller, 554 U.S. 570 (2008).

17. Perhaps the major example of originalism's prominence in the legal academy is Jack Balkin's adoption of it. JACK M. BALKIN, LIVING ORIGINALISM (2011).

18. See NFIB v. Sebelius, 132 S. Ct. 2566, 2576-82, 2584-93 (2012) (Roberts, C.J., opinion) (coming to conclusions consistent with the Commerce Clause's original meaning without expressly relying on the original meaning and primarily working with and within precedent); see also Josh Blackman, Back to the Future of Originalism, 16 CHAP. L. REV. 1,25 (2013) (describing a facet of originalism's gravitational effect).

19. See, e.g., PAUl Johnson, A History OF Christianity 268-81 (1976) (listing, as causes, unseemly wealth within the Church, clerical abuses, dissolution of the Thomistic philosophical synthesis, rediscovery of ancient learning, overburdensome religious requirements, urbanization, an educated and economically prosperous laity, the printing press, nascent nationalism, growth of the state and dynastic ambition, and papal insolvency).

20. Id.; Brad S. GRegory, The Unintended Reformation: How A RELIGIOUS REVOLUTION SECULARIZED SOCIETY 366 (2012) ("The failure of medieval Christendom derived . . . from the pervasive, long-standing, and undeniable failure of so many Christians, including members of the clergy both high and low, to live by the church's own prescriptions and exhortations based on its truth claims about the Life Questions."); see also EAMON DUfFy, STRIPPING OF THE Alters: Traditional RELIGION IN ENGLAND 1400-1580 at 479 (Yale Univ. Press 2d ed. 2005) (1992) (attributing the English reformation to the "social and economic prestige of its more prosperous or articulate adherents").

21. Some originalists reject construction, some accept a moderate role for construction, while others believe that construction plays a robust role.

22. Originalists fall on a spectrum, with some originalists accepting little or no nonoriginalist precedent, and others accepting some (possibly significant) subset of 
!!!StrANG-291-ChALLENGESOFANDCHALLENGESTOORIGINALISM.DOC (Do Not Delete)8/9/2013 3:37 PM

originalism, ${ }^{23}$ and the normative justification for originalism. ${ }^{24}$ Over each of these four divisions (among others), originalists have articulated increasingly complex arguments for and against their respective positions. These cleavages potentially pose a challenge to originalism's integrity, in a way similar to the debates among Christians during the Reformation.

However, Smith's use of "scholastic"-though it carries, in Smith's usage, the conventional negative connotation ${ }^{25}$ - suggests an alternative era when incredibly sophisticated and nuanced debates proceeded within a context of overarching unity: the period of the First Scholasticism. ${ }^{26}$ The twelfth and thirteenth centuries were a period of tremendous intellectual ferment in the West, for a host of reasons, and Christian scholars engaged each other (and non-Christians) with great erudition-and disagreement-while maintaining the overall coherence of their perspective. It was not until the Reformation, precipitated by causes other than theological sophistication, that Christianity fractured.

Similarly, originalists are engaged with each other (and their critics) in a sophisticated debate. There is no necessary reason why intra-originalist disagreements must fracture the overall

nonoriginalist precedent.

23. The various major forms are: original intent, original understanding, original meaning, and original methods.

24. There are two general categories of justifications offered by originalists: internal and external. KEITH E. WhITTINGTON, CONSTITUTIONAL INTERPRETATION: TEXTUAL MEANING, ORIGINAL INTENT, AND JUDICIAL REVIEW 110 (1999). Internal justifications accept the premises and facets of the current practice, and argue that originalism is the best explanation for that practice. For instance, Professor Whittington claimed that originalism is required by our practice's commitment to a written constitution. Id. External justifications, by contrast, argue that originalism does better than alternatives at maximizing some good or set of goods. Id. at 110-11. For example, Professor Barnett argued that originalism's "lock-in" of the Constitution's original meaning best protects the original meaning's ability to protect natural rights. RANDY E. BARNETT, RESTORING the Lost COnstitution: The Presumption OF Liberty 109-17 (2004). This external" category is similar to Professor Berman's soft originalism category (pp. 25354).

25. See also Steven D. Smith, Natural Law and Contemporary Moral Thought: A Guide from the Perplexed, 42 AM. J. JURIS. 299, 299 (1997) (using "scholastic" in the conventional, negative sense).

26. See Fergus Kerr, After Aquinas: Versions of Thomism 8 (2002) ("Disputation as a method assumes there will be conflicting interpretations of texts and doctrines that need to be exposed, explored and resolved."); see also ALASDAIR MACINTYRE, THREE RIVAL VERSIONS OF MORAL ENQUIRY: ENCYClOPEDIA, GeNEAlogy, AND TRADITION 222-24, 232-34 (1990) (describing the premodern university as one of "[c]reative rational disagreement... against a background of agreement"); JOSEF PIEPER, SCHOlasticism: Personalities AND PROBLEMS IN Medieval Philosophy (Richard \& Clara Winston trans., St. Augustine's Press 2001) (1960) (describing the Scholastic period). 
!!!Strang-291-ChallengesofandChallengestoOriginalisM.DOC (Do Not Delete)8/9/2013 3:37 PM

originalist perspective. Instead, the Scholastic experience suggests that long-term, constrained-though-creative, disagreement is possible-and fruitful.

\section{B. ORIGINALISM'S BROAD RESONANCE}

The Challenge of Originalism also exemplifies originalism's broad resonance with scholars from many different backgrounds. Originalist contributors include long-time and relatively recent advocates, Americans and scholars from other countries, and scholars of varied political backgrounds. Something about originalism - the power of its arguments, its fit with pre-existing legal, cultural, or social structures, or, potentially, the ideological cover it provides - is attracting a variety of scholars.

In addition to prominent American originalists, ${ }^{27}$ The Challenge of Originalism includes contributions by Jeffrey Goldsworthy and James Allan, Australian legal scholars, and Grant Huscroft and Bradley W. Miller, Canadian law professors. For American scholars who, typically, read American legal scholarship, the essays by these scholars are enriching for a number of reasons.

First, the essays by Goldsworthy, Allan, Huscroft, and Miller exemplify originalism's attractiveness to non-American scholars. ${ }^{28}$ For example, Goldsworthy believes that the argument in favor of originalist interpretation is "simple, straightforward, and powerful" (p. 42).

Second, the essays by non-American scholars provide new and-for American scholars, I suspect-fresh perspectives on originalism. For instance, Allan's argument for originalism begins at an unfamiliar place: the hypothetical country of Allania, which moved from "a legally unchecked legislature" to adoption of a written constitution (p. 181).

At the same time as The Challenge of Originalism exemplifies the breadth of originalism's resonance, it also suggests that originalism's appeal is limited. The arguments made by both the American and non-American scholars focus or depend on written constitutions. Most clearly, Grégoire C.N. Webber's essay abstracts from any particular constitution or

27. In this Volume are chapters by Larry Alexander, Stanley Fish, Lawrence B. Solum, and Keith E. Whittington.

28. Each author writes against the background of a written constitution, either actual, in the cases of Goldsworthy (Australia), Huscroft (Canada), and Miller (Canada), or hypothetical (Allan). 
!!!StrANG-291-ChALLENGESOFANDCHALLENGESTOORIGINALISM.DOC (Do Not Delete)8/9/2013 3:37 PM

country in order to ascertain the characteristics of a constitution necessary to make originalism an appropriate interpretative methodology (pp. 147-78). Webber concludes that originalism requires, among other things, a commitment to "an original constitution that is written at the founding" (p. 151).

\section{ORIGINALISM'S OWN CHALLENGES}

As The Challenge of Originalism shows, originalism poses a significant intellectual challenge, not only in the United States, but in other countries (with written constitutions) as well. The Challenge of Originalism also, as discussed above, includes a number of essays that voice challenges to originalism. In this Part, I briefly discuss two additional challenges facing originalists: (1) fully explaining the nature and scope of constitutional construction; and (2) describing what role, if any, nonoriginalist precedent retains in originalism. Both of these challenges share the common, and deeper, problem posed by originalism's fit, or lack thereof, with current legal practice.

A major hurdle facing originalism, as articulated by original meaning originalists, is its significant reliance on constitutional construction. Originalists who advocate for constitutional construction still have a lot of work to do elucidating construction: what is the evidence that construction is a necessary facet of originalism?; when does it occur?; what is the "output" of construction?; what relationship does it have to interpretation?; how does one know when or where interpretation leaves off and construction begins?; and, what is the relative authority of judges, compared to the other branches of the federal government, ${ }^{29}$ when articulating constructions? Until these central questions are fully fleshed out, it is reasonable for other originalists, and nonoriginalists, to remain skeptical of the move, for a host of reasons.

To focus only on the most basic question-why must construction form a part of originalism? - it seems, at least to me, ${ }^{30}$ that the underdeterminacy of constitutional meaning is prima facie, a reasonable position. But, what if the best conception of originalism contains one or more closure rules

29. And state governments.

30. See Lee J. Strang, An Originalist Theory of Precedent: The Privileged Place of Originalist Precedent, 2010 BYU L. REV. 1729, 1758-62 (describing the distinction between metaphysical and epistemic determinacy of law and how it may support the concept of constitutional construction). 
!!!Strang-291-ChallengesofandChallengestoOriginalisM.DOC (Do Not Delete)8/9/2013 3:37 PM

that, in all (or nearly all) possible cases, result in determinate answers to constitutional interpretative questions $?^{31}$ To date, pro-construction originalists have not provided fully fleshed-out responses in the legal literature. ${ }^{32}$ Recognizing this gap, proconstruction originalists have continued to offer arguments and explanation. $^{33}$

Despite the broad array of arguments displayed by originalists (and their interlocutors) in The Challenge of Originalism, some of the outstanding issues with which originalists have grappled were not addressed, or were raised tangentially. Most prominent among these is the challenge posed by nonoriginalist precedent (p. 252 (Berman)). Originalists have approached nonoriginalist precedent in a number of ways, ${ }^{34}$ but the reader would not know that from The Challenge of Originalism.

One can describe the challenge posed by nonoriginalist precedent in a number of ways. The first way is that, if originalism does incorporate some/most/all nonoriginalist precedent, then it risks losing (at least some of) what makes it distinctive.

A second way to describe the challenge posed by nonoriginalist precedent is that originalism does not adequately fit American constitutional law because so much of it is composed of nonoriginalist precedent. This description ties this challenge to the prior one: constitutional construction. Both of these major, outstanding challenges hinge on the practical fact that our written Constitution's original meaning does not account for key components of and large quantities of American

31. See, e.g., McGinnis \& Rappaport, supra note 5, at 773 (suggesting that original closure rules eliminate potential underdeterminacy and, hence, the need for constitutional construction).

32. See, e.g., Randy E. Barnett, Interpretation and Construction, 34 HARV. J.L. \& PUB. POL'Y 65, 71-72 (2011) (offering a brief rejoinder to McGinnis and Rappaport); Lawrence B. Solum, The Interpretation-Construction Distinction, 27 CONST. COMMENT. 95, 105 n.21 (2010-2011) (responding to McGinnis and Rappaport in a footnote, and noting that "complete treatment is outside the scope of this Essay").

33. See, e.g., Solum, supra note 32, at 103-08 (providing an explanation of construction as "giv[ing] legal effect to the semantic content of a legal text").

34. John O. McGinnis \& Michael B. Rappaport, Reconciling Originalism and Precedent, 103 Nw. U. L. REV. 803 (2009); Gary Lawson, Mostly Unconstitutional: The Case Against Precedent Revisited, 5 Ave Maria L. ReV. 1 (2007); Kurt T. Lash, Originalism, Popular Sovereignty, and Reverse Stare Decisis, 93 VA. L. REV. 1437 (2007); Randy E. Barnett, Trumping Precedent with Original Meaning: Not as Radical as It Sounds, 22 CONST. Comment. 257 (2005); Lee J. Strang, An Originalist Theory of Precedent: Originalism, Nonoriginalist Precedent, and the Common Good, 36 N.M. L. REV. 419 (2006). 
!!!StrANG-291-ChALLENGESOFANDCHALLENGESTOORIGINALISM.DOC (Do Not Delete)8/9/2013 3:37 PM

constitutional law. ${ }^{35}$ For both the issue of construction and the issue of nonoriginalist precedent, originalists face the same tensions: maintain originalism's distinctiveness or lose it; fit the Constitution's original meaning or fit the practice more broadly.

The broad, international cadre of originalist contributors shows that originalism faces many of these same challenges and criticisms in countries with different legal systems and historical circumstances. For instance, Bradley Miller's essay shows that, for originalism to succeed in Canada, it must grapple with and synthesize Edwards v. AG Canada, commonly known as the Persons Case (pp. 120-46). The Persons Case is Canada's Brown v. Board of Education ${ }^{37}$ because it is a key case in the canon $^{38}$ of Canadian constitutional law. The Persons Case is widely viewed as reaching a just result via a nonoriginalist methodology (pp. 120-21). Miller argues that the Persons Case is actually an example of original meaning originalism and, therefore, originalism can reach the necessary just result (pp. 122-44). Miller relies on the concept of constitutional construction and shows that the key term, "person," was ambiguous, and that originalism permitted a just construction of the term (pp. 138-44).

Similarly, Grant Huscroft describes another common nonoriginalist move (pp. 203-22). In Canada, as in the United States, nonoriginalists frequently argue that constitutional text is-intentionally or not-vague because of its high level of generality, and that originalism is therefore inappropriate for such texts. In arguments that echo those leveled against Jack Balkin, ${ }^{39}$ Huscroft argues that bills of rights in general, and the Canadian Charter of Rights and Freedoms in particular, "reflect the bargaining and compromise that was required in order to attain the political consent necessary to entrench it in the constitutional order" (p. 204). Therefore, bills of rights are "finite," and originalism offers a principled means for judges to acknowledge and follow that finiteness (pp. 204-05, 218).

35. Strang, supra note 34 , at $430-32$

36. Edwards v. Attorney-General for Canada, [1930] A.C. 124 (P.C.) [more commonly known as the Persons Case].

37. 347 U.S. 483 (1954).

38. J.M. Balkin \& Sanford Levinson, Commentary, The Canons of Constitutional Law, 111 HARV. L. REV. 963 (1998).

39. See John O. McGinnis \& Michael B. Rappaport, The Abstract Meaning Fallacy, 2012 U. ILL. L. REV. 737 (criticizing Professor Balkin's "preference for abstract interpretations"). 
!!!STRANG-291-ChALlENGESOFANDCHALlENGESTOORIGINALISM.dOC (Do Not DELETE)8/9/2013 3:37 PM

\section{ORIGINALISM'S CONTINUING ALLURE: THE CHALLENGE POSED BY WRITTENNESS}

If ever a theory of constitutional interpretation faced challenges, it is originalism. ${ }^{40}$ Demographically, originalists have been and continue to be a relatively small portion of the legal academy. ${ }^{41}$ As a matter of brute practical fact, much of current American constitutional law and interpretative practice is in tension with the Constitution's original meaning. ${ }^{42}$ As importantly, originalism has been, since it first took the stage, the recipient of continual-and frequently highly-sophisticatedcriticism. ${ }^{43}$ The Challenge of Originalism prompts the question of why originalism - despite these and other challenges ${ }^{44}$ - has not only not died a quiet death: it has flourished.

There are a number of reasons for originalism's continuing allure; I will focus on one that closely fits the essays in The Challenge of Originalism: the fact of the Constitution's writtenness. ${ }^{45}$ This fact, more than anything else, I think, accounts for originalism's staying power. Pointing to the Constitution's writtenness as an important facet of originalism's pull is not new. Though scholars across the interpretative spectrum have made this point, ${ }^{46}$ the essays in The Challenge of Originalism exemplify

40. See, e.g., BARNETT, supra note 24 , at $89-90$ ("The received wisdom among law professors is that originalism in any form is dead, having been defeated in intellectual combat sometime in the 1980s.").

41. See Lee J. Strang, Originalism as Popular Constitutionalism?: Theoretical Possibilities and Practical Differences, 87 Notre DAME L. ReV. 253, 279-88 (2011) (describing the relationship between political outlook and interpretative method); see also John O. McGinnis et al., The Patterns and Implications of Political Contributions by Elite Law School Faculty, 93 GEO. L.J. 1167, 1170 (2005) (finding that " $81 \%$ of law faculty members in the study who make political contributions contribute wholly or predominately to Democrats"); Symposium, Curricular Stress, 60 J. LEGAL EDUC. 110, 112 (2010) ("To be sure, many law professors - probably a substantial majority - have liberal rather than conservative political views ....").

42. Strang, supra note 34, at 430-32. 29).

43. Professor Solum details originalism's evolution in response to criticism (pp. 16-

44. For instance, Americans prefer at least some nonoriginalist precedents and doctrines over the original meaning.

45. The Constitution's writtenness also plays a central role in originalist thought outside the essays in The Challenge of Originalism. See, e.g., BARNETT, supra note 24, at 91 ("Once the importance of text or 'writtenness' is conceded, some version of originalism becomes must harder to resist."); WHITTINGTON, supra note 24, at 47 (defending the "claim that an originalist interpretive approach is somehow required by the very fact that the United States has a written constitution"); see also Andrew B. Coan, The Irrelevance of Writtenness in Constitutional Interpretation, 158 U. PA. L. REV. 1025, 1027-28 (2010) (describing the widespread originalist appeal to the Constitution's writtenness).

46. As Professor Berman summarizes the nonoriginalist perspective, "the original public meaning of the constitutional text and the original semantic intentions of its 
!!!StrANG-291-ChALLENGESOFANDCHALLENGESTOORIGINALISM.DOC (Do Not Delete)8/9/2013 3:37 PM

the tight connection between originalism and written constitutionalism.

Professor Solum's initial essay ${ }^{47}$ describes originalism's two core theses, both of which are predicated on the Constitution's writtenness (pp. 32-38). Professor Goldsworthy's essay is likewise predicated on a written constitution. ${ }^{48}$ Professor Miller's essay seeks to reconcile, in the Canadian context, originalism's fealty to constitutional text with the claims of justice presented in the Persons Case (pp. 120-22).

The Constitution's writtenness also accounts for major intra-originalist disputes, such as the debate between original intent and original meaning originalists. Both sides in this debate contend that they are more faithful to how one does and should interpret written documents, like the Constitution. For example, Larry Alexander contends that original intent best accounts for Americans' fealty to the written document in the national $\operatorname{archives}^{49}$ (pp. 93-94). Similarly, Stanley Fish's argument is textcentric: "My answer to the question 'What is the meaning of a text?' is simple and categorical: A text means what its author or authors intend" (p. 100).

Grégoire Webber's essay, "Originalism's Constitution," focuses on the relationship between originalism and its "subject matter of interpretation," which, Webber argues, "cannot so easily be divorced from an interpretative approach" (p. 150). Webber concludes that originalism has three core commitments, including that an originalist constitution "is written" Grant Huscroft makes a similar move in the Canadian context by arguing that adoption of the Canadian Charter of Rights and Freedoms has the interpretative consequence that the adopted rights are the only rights constitutionally protected because "bills

authors are relevant" (p. 248). See also p. 250 ("Virtually nobody denies that the original meaning of a constitutional provision is always relevant to the interpretative task, and few theorists deny that it is frequently a weighty consideration.").

47. Professor Solum's other work, especially his unpublished paper, also rests on the Constitution's writtenness. See Lawrence B. Solum, Semantic Originalism, http://papers.ssrn.com/sol3/papers.cfm?abstract_id=1120244 (last updated Nov. 25, 2008).

48. See also Whittington (p. 71) (summarizing his view that "originalism is the best approach to interpreting a written constitution").

49. See also Larry Alexander, Introduction, in CONSTITUTIONALISM: PHILOSOPHICAL FOUNDATIONS 1-5 (Larry Alexander ed., 1998) (making a similar point); Kay, supra note 11 , at 29-30 (same).

50. Webber also plays out implications of originalism's need for writtenness: the original constitution's meaning is tied to a particular historical event (p. 152); the original constitution's text is a fixed reference for constitutional meaning (p. 153); and the original constitution's text's meaning is "discoverable as a 'social fact"” (p. 153). 
!!!Strang-291-ChallengesofandChallengestoOriginalisM.DOC (Do Not Delete)8/9/2013 3:37 PM

of rights are finite instruments" (p. 204). Relatedly, James Allan contends that, based on the reasons a polity would adopt a written constitution in the first instance, "originalism is the least bad (or, in that sense, the best) approach to interpreting it" (p. 181).

Conversely, originalism's critics in The Challenge of Originalism question whether the Constitution's writtenness leads to the originalists' conclusions. For instance, Professor Berman tentatively proffers a "complex" theory of constitutional interpretation that would have places for "arguments of text" and of original meaning, and that gives these and other reasons different weights, but which would not give original meaning conclusive weight (pp. 275-77). Professor Bix questions whether originalism can plausibly apply to all constitutions or is limited to the U.S. Constitution (pp. 292-98).

In addition to being addressed by the essays, the Constitution's writtenness also accounts for the continuing discussion over the two challenges to originalism I earlier identified: the role of constitutional construction and the viability of nonoriginalist precedent. One of constitutional construction's key characteristics is that it identifies the limits to the text's reach: the limits to the written Constitution's power to bind. Originalists currently fracture on the extent of the Constitution's constraint on constitutional construction. ${ }^{51}$ Similarly, nonoriginalist precedent presents originalists with the conflict between the written Constitution and contrary Supreme Court pronouncements. Originalists have also not achieved consensus on how to resolve that conflict. ${ }^{52}$

Professor Smith's essay, described above, ${ }^{53}$ worries that originalism's sophistication may lead to exclusion of all but the most stout hearted from the debate and the possible dissolution of originalism itself (pp. 227-33). I suggested earlier that sophistication may not result in exclusion, or that potential exclusion may be a cost worth bearing, and that it is not clear that sophistication will lead to dissolution. Let me now suggest that the sophistication so ably displayed in The Challenge of

51. See Solum, supra note 8, at 166-68 (describing how originalists have different views on the constraint the Constitution's original meaning imposes on constitutional construction).

52. See sources cited, supra note 34 (providing a selection of the contending approaches)

53. Supra Part II.A. 
!!!StrANG-291-ChALLENGESOFANDCHALLENGESTOORIGINALISM.DOC (Do Not Delete)8/9/2013 3:37 PM

Originalism is the result of our commitment to a written constitution.

Texts that play central roles in human culture, practices, and institutions, accumulate around them ever-more sophisticated engagement with those texts. Returning to Smith's analogy to religion, Christians' and Christianity's engagement with the Bible, from its inception, grew in complexity. Christians, for example, grappled with (their understanding of) the nature of Jesus Christ, and his relationship to God the Father and Holy Spirit, only after facing new historical and theological circumstances that the Bible did not-at least not perspicaciously-answer. ${ }^{54}$ As Christianity more fully articulated the doctrine of the Trinity, both the doctrine itself and the arguments supporting it, created a complex intellectual architecture. $^{55}$

The Constitution's central role in American cultural, political, and legal life make similar sophistication of constitutional law and interpretation inevitable. Americans care about how and what the Constitution means, and increased sophistication is one result of attempts to answer those questions.

\section{CONCLUSION}

The Challenge of Originalism is accessible to the newlyinitiated while remaining worthwhile for those deeply engaged in the debates over originalism. The Challenge of Originalism showcases the broad appeal of originalism and the subtlety with which its proponent and opponents engage. The Challenge of Originalism also displays the centrality of the Constitution's writtenness to originalism. Lastly, The Challenge of Originalism reminds us that there remains a great deal for originalists to do, especially further explanation of constitutional construction and the status of nonoriginalist precedent.

54. See Newman, supra note 14, at 14-21 (describing the background and development of the doctrine of the Trinity).

55. See, e.g., Saint Thomas Aquinas, Summa Theologica I, QQ. 27-43 (Benziger Bros. ed., Fathers of the English Dominican Province trans., 1947) (1273) (explaining the now-complex doctrine of the Trinity). 